\title{
Evaluation of implicit emotion in the message through emotional speech processing based on Mel-Frequency Cepstral Coefficient and Short-Time Fourier Transform features
}

\author{
Mahsa Ravanbakhsh ${ }^{1}$, Saeed Setayeshi ${ }^{2 *}$ iD , Mir Mohsen Pedram ${ }^{3}$, Azadeh Mirzaei ${ }^{4}$
}

\begin{abstract}
1. PhD Student of Cognitive Linguistics, Institute for Cognitive Science Studies (ICSS), Tehran, Iran
2. Associate Professor of Department of Physics and Energy Engineering, Amirkabir University of Technology, Tehran, Iran

3. Associate Professor, Department of Electrical and Computer Engineering, Kharazmi University, Tehran, Iran

4. Assistant Professor of Linguistics, Department of Linguistics, Faculty of Persian Literature and Foreign Languages, Allameh Tabataba'i

University, Tehran, Iran
\end{abstract}

Recieved: 28 Apr. 2019

Revised: 1 Dec. 2019

Accepted: 10 Dec. 2019

\section{Keywords}

Emotional speech

Emotion recognition

Short time Fourier transform

Mel-frequency Cepstral coefficients

Emotional speech processing

Corresponding author

Saeed Setayeshi, Associate Professor of Department of Physics and Energy Engineering, Amirkabir University of Technology, Tehran, Iran

Email: Setayesh@aut.ac.ir

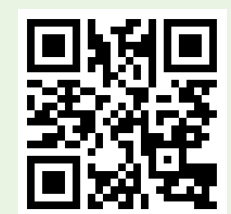

doi.org/10.30699/icss.22.2.71

\section{Abstract}

Introduction: Speech is the most effective way to exchange information. In a speech, a speaker's voice carries additional information other than the words and grammar content of the speech, i.e., age, gender, and emotional state. Many studies have been conducted with various approaches to the emotional content of speech. These studies show that emotion content in speech has a dynamic nature. The dynamics of speech make it difficult to extract the emotion hidden in a speech. This study aimed to evaluate the implicit emotion in a message through emotional speech processing by applying the Mel-Frequency Cepstral Coefficient (MFCC) and Short-Time Fourier Transform (STFT) features.

Methods: The input data is the Berlin Emotional Speech Database consisting of seven emotional states, anger, boredom, disgust, anxiety/fear, happiness, sadness, and neutral version. MATLAB software is used to input audio files of the database. Next, the MFCC and STFT features are extracted. Feature vectors for each method are calculated based on seven statistical values, i.e. minimum, maximum, mean, standard deviation, median, skewness, and kurtosis. Then, they are used as an input to an Artificial Neural Network. Finally, the recognition of emotional states is done by training functions based on different algorithms. Results: The results revealed that the average and accuracy of emotional states recognized using STFT features are better and more robust than MFCC features. Also, emotional states of anger and sadness have a higher rate of recognition, among other emotions.

Conclusion: STFT features showed to be better than MFCC features to extract implicit emotion in speech.

Citation: Ravanbakhsh M, Setayeshi S, Pedram M, Mirzaei A. Evaluation of implicit emotion in the message through emotional speech processing based on Mel-Frequency Cepstral Coefficient and Short-Time Fourier Transform features. Advances in Cognitive Sciences. 2020;22(2):71-81. 


\title{
ارزيابى هيجان ضمن ييام از طريق يردازش كفتار هيجانى مبتنى بر استفاده از ويز كىهاى MFCC و STFT
}

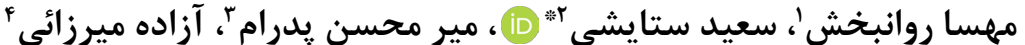

، دانشجوى دكترى زبان شناسى شناختى، موسسه آموزش عالى علومشناختى، تهر ان، ايران

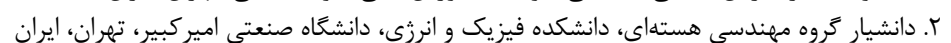

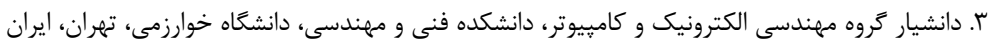

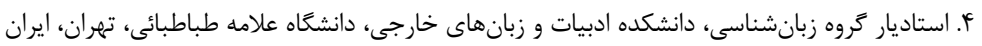

\section{ars}

مقلدمه: كَفتار مؤثرترين ابزارى است كه انسانها براى انتقال اطلاعات از آن استفاده مى كنند. كوينده در خلال كَفتار

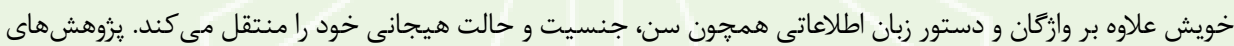
فراوانى با رويكردهاى گوناكون يِيرامون هيجان در Fفتار هيجانى انجام شده است. اين يروهشها نشان مىدهند كه هيجان ضمن پيام در كفتار هيجانى از طبيعتى يويا برخودار مىباشد. اين يويايى، مطالعه كمّى هيجان در كَفتار هيجانى را با دشوارى همراه مىسازد. اين يزوهش به ارزيابى هيجان ضمن پيام از طريق يردازش كفتار هيجانى با استفاده از ويرَّى هاى ضرايب كِيسترال فركانس مِل (MFCC) و تبديل فوريه زمان كوتاه (STFT) برداخت. روش كار: دادههاى ورودى، پِايكاهداده استاندارد كَفتار هيجانى Berlin شامل هفت حالت هيجانى خشم، كسلى، انزجار، ترس، شادى، غم و حالت خنثى مىباشد. با استفاده از نرم افزار MATLAB ابتدا فايلهاى صوتى خوانده شدند. در مرحله بعد نخست ويزَى هاى MFCC و سيس ويزگى هاى STFT استخراج شدند. بردارهاى ويزَى براى هر كدام از ويزَكى ها بر اساس هفت مقدار آمارى كمينه، بيشينه، ميانگين، انحراف معيار، ميانه، جولكَى و كشيدكى محاسبه شدند و به عنوان ورودى شبكه عصبى مصنوعى مورد استفاده قرار گرفتند. در انتها، بازشناسى حالتهاى هيجانى با استفاده از توابع آموزشى مبتنى بر الكوريتمهاى مختلف انجام شد.

يافته ها: نتايج بدست آمده نشان داد ميانكين و صحت بازشناسى حالتهاى هيجانى با استفاده از ويزگىهاى STFT نسبت به ويثگى هاى MFCC بهتر است. همجنين، حالتهاى هيجانى خشم و غم از نرخ بازشناسى بهترى برخوردار بودند.

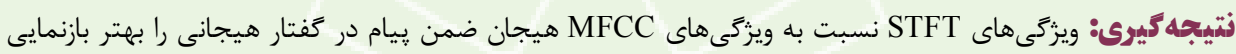

دوريافت: د

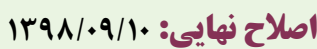

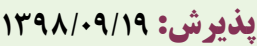
وازٔههاى كليدى كفتار هيجانى بازشناسى هيجان

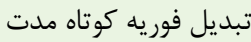

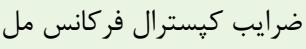
ييردازش كفتار هيجانى نويسنله مسئول سعيد ستايشى، دانشيار گروه مهندسى هستهاى، دانشكده فيزيك و انرزى، دانشعاه داهي صنعتى امير كبير، تهران، ايران ايميل:Setayesh@aut.ac.ir

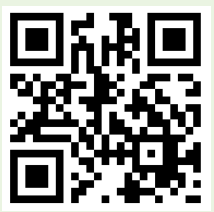

dol doi.org/10.30699/icss.22.2.71

مقدمه

است ويزگ هاى مناسبى از سيخنال گفتار هيجانى استخراج شود كه بتوانند به نحو شايانى حالتهاى هيجانى ضمن ريام در كفتار را بازنمايى كنند. البته در كامىهاى بعدى استفاده از طبقهبندى كنندهاى كه بتواند به درستى حالتهاى هيجانى را بازشناسى كند از اهميت ويزهاى برخوردار است. بازشناسى حالتهاى هيجانى ضمن :ييام در گفتار هيجانى با عنوان
كفتار ابزارى است كه انسان از آن براى ارتباط با ديخران و انتقال اطلاعات استفاده مى كند. هر كفتار علاوه بر وازگًان و دستور زبان خاص هر زبان حاوى اطلاعات ديخرى از جمله سن، جنسيت و حالت هيجانى گوينده آن نيز مىباشد. مطالعه كمّى حالتهاى هيجانى ضمن ييام در كفتار هيجانى بسيار دشوار است. براى غلبه به اين دشوارى در گام نخست لازم 
به اين كه ويزگگىهاى استخراج شده از ابعاد بالايى برخوردار هستند، با

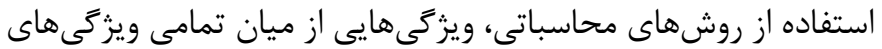
استخراج شده انتخاب مىشوند تا هر نمونه در قالب يك بردار بازنمايى شود. اين بردارها به عنوان بردارهاى ورودى براى طبقهبندى كننده

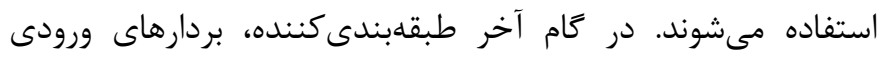
را دستهبندى مى كند و به بازشناسى حالتهاى هيجانى مىيردازد. خروجى طبقلبندى كننده، حالتهاى هيجانى بازشناسى شده هستند.
بازشناسى هيجان گفتار (Emotion Speech Recognition) شناخته مىشود. با بررسى يزوهشهاى انجام گرفته در زمينه بازشناسى هيجان

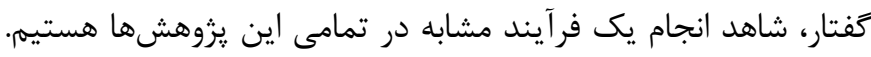
شكل ا مراحل مشترك انجام بازشناسى حالتهاى هيجانى در كفتار هيجانى را نشان مى ندهد.

همانطور كه در تصوير مشاهده مىشود، ابتدا از نمونههاى سيخنال كفتار هيجانى ويزگى هايى استخراج مى گردد. در مرحله بعد با توجه

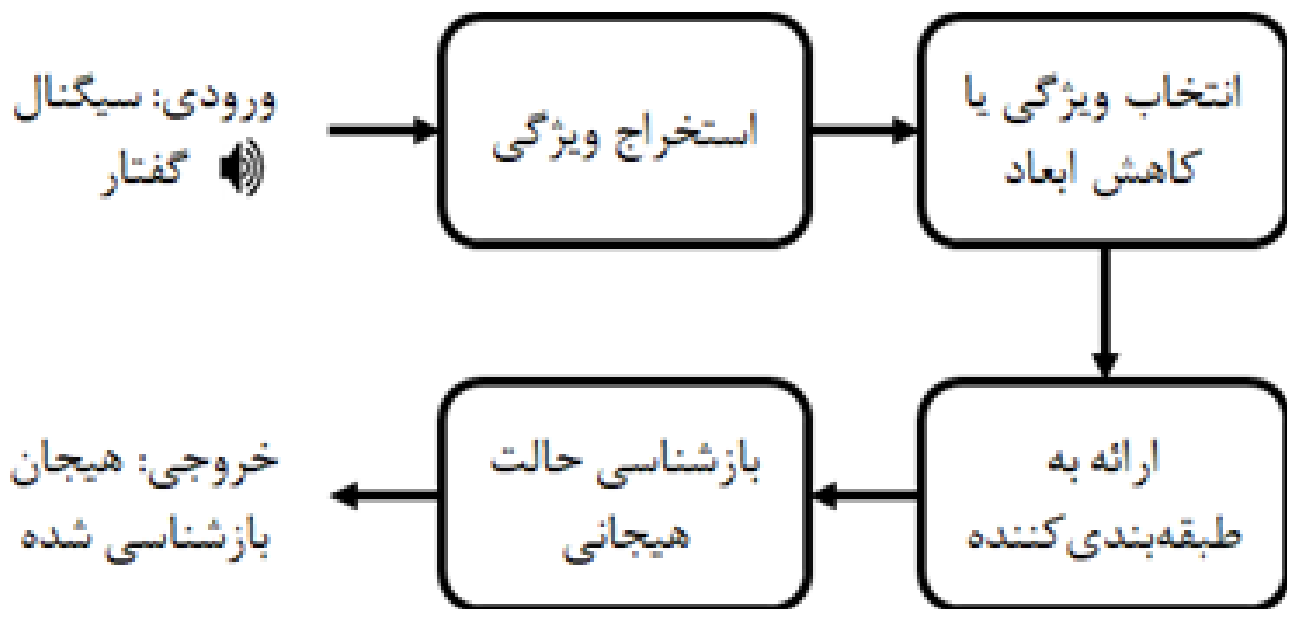

شكل 1. مراحل بازشناسى هيجان كَفتار

همكاران (ه) از شبكههاى عصبى مصنوعى براى بازشناسى و طبقهبندى حالتهاى هيجانى كفتار استفاده كردند. Franti و همكاران شبكههاى بـ بـ عصبى كانولوشن را به عنوان طبقهبندى كننده مورد استفاده قرار دادند (9). علاوه بر اين روشها، از شيوههاى ديخرى همجون مدل تركيبى رئ Gaussian

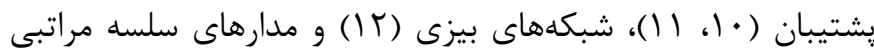

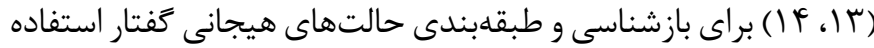
شده است. همجنين از روشهاى نوينى جون مدلهاى شناختى از جمله مدل (Brain Emotional Learning (BEL) براى بازشناسى

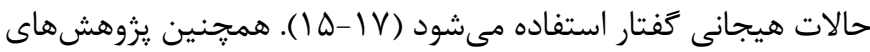
فراوان ديخرى براى درك يِيجيدگى هاى زيستى سيستهم شنوايى انجام گرفتهاند؛ Golipour و Gazor يك مدل براى سيستم شنوايى ارائه كردند كه يِيجيد تمامى سيحنال هاى ورودى به گوش از جمله گفتار را در نظر مى گرفت (1)). آنها براى بررسى تغييرات فر كانسها در طى زمان و اثر آنها بر رفتار بخشهاى مختلف گَش از ويزگى هاى تبديل فوريه زمان كوتاه (Short Time Fourier Transform (STFT))
دو رويكرد قالب در بازشناسى هيجان كفتار وجود دارد. در رويكرد نخست موضوع مورد بررسى استخراج و ارائه ويزگى هايى از سيخنال صوتى گفتار است كه به بهترين وجه بتواند حالتهاى هيجانى را بازنمايى كند. در

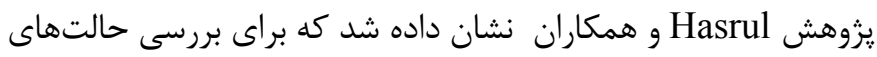
هيجانى، ويزگگىهاى گام (Pitch)، انرزى، شدت، فرمانت، ديرش، ضرايب كيسترال فر كانس مل (MFCC)) و وشتقات آن بيش از ساير ويزگ (Mel-Frequency قرار گرفتهاند (1). در اين ميان MFCC بيش از ساير ويزگىهاى براى بازشناسى هيجان گفتتار مورد استفاده قرار گرفتهاند (1). اما در رويكرد دوم موضوع مورد بررسى انواع طبقهبندى كنندهها، طراحى و بهينهسازى آنها مىباشد. در ادامه جند نوع از طبقهبندى كنندههاى به كار رفته در جند يزوهش را معرفى مىكنيم. Demircan و

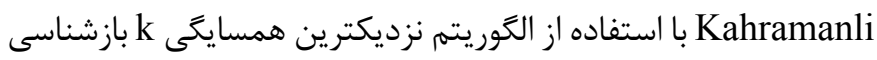
حالت هيجانى در كفتار هيجانى را انجام دادند (r). در يزوهشى ديخر Nwe كفتار بر اساس Hidden Markov Model به عنوان دستهبندى كننده ارائه كردند (ץ) و و همكاران (Y) و و همجنين Nicholitha و 
ترتيب شيوه محاسبه ويزگى هاى MFCC و STFT را شرح خواهيم داد.

ضرايب كيسترال فر كانس مل (MFCC) ويزگى هايى هستند كه از خواص شنيدارى گَوش انسان در

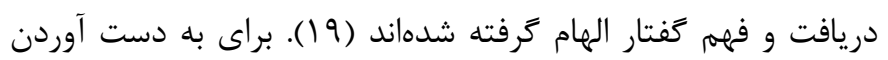
ويزگكىهاى MFCC نخست بايد طيف فوريه ينجره (فريم) با استفاده

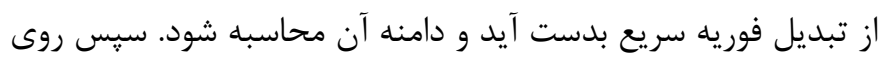
طيف بدست آمده به صورت لكاريتمى و بر اساس معادله ( (1) بانك فيلتر اعمال مىشود و خروجى فيلتر محاسبه مىشود.

$$
F_{m e l}=\text { rهqr } \log _{1} \cdot\left[1+\frac{F_{H z}}{r \cdot \cdot}\right]
$$

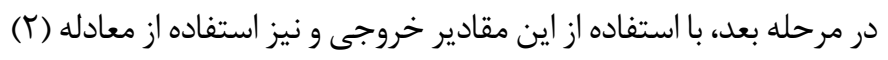

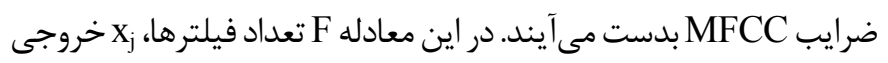

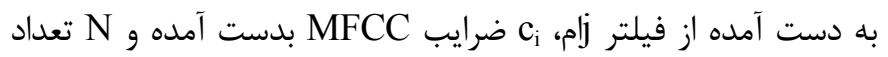
ضرايب MFCC مىباشند. شكل r ضرايب MFCC محاسبه شده براى

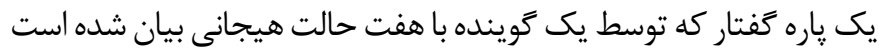

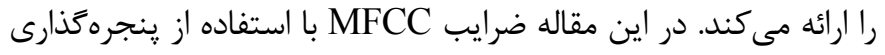

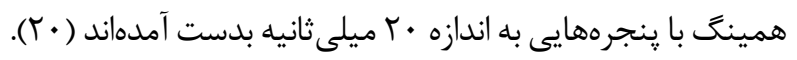

$$
c_{i}=\sum_{j=1}^{N} \log \left(x_{j}\right) \cos \left[\frac{\pi_{i}(j-\cdot / \Delta \Delta)}{F}\right], \quad \leq i \leq F
$$

در اين مطالعه قصد داريم تا با استفاده از يك شبكه عصبى مصنوعى

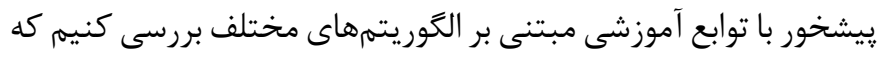

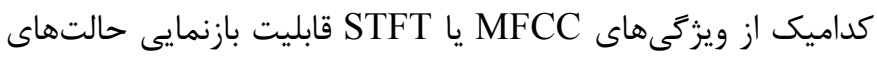
هيجانى را بهتر انجام مى دهند و كمك مى كنيند كه حال حالتهاى هيجانى با نرخ بهترى بازشناسى شوند.

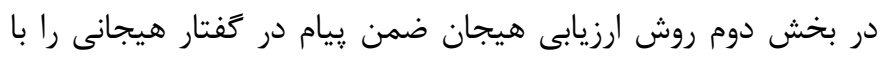
استفاده از شبكه عصبى مصنوعى مبتنى بر ويزگى هاى MFCC و

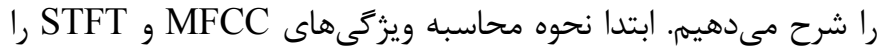
توضيح مىدهيم. سيس معمارى شبكه عصبى مصنوعى مورد استفاده

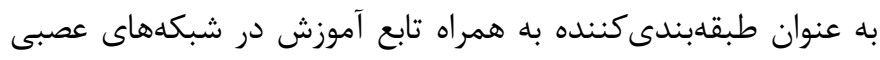

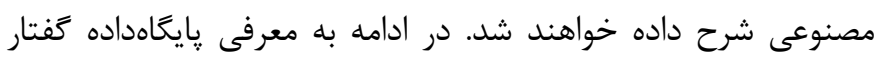

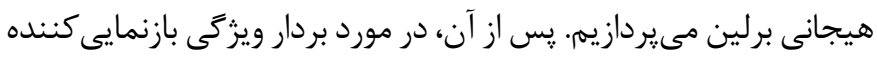

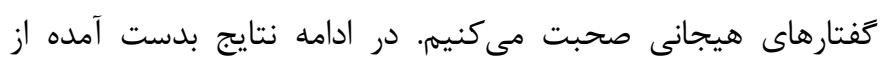

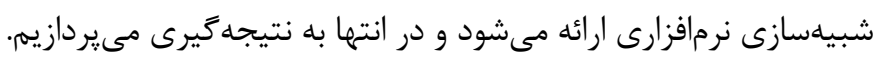

\section{روش كار}

محاسبه و استخراج ويزگى هاى آكوستيكى كفتار

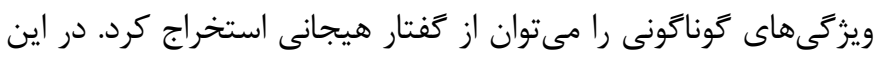

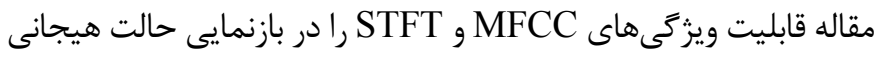
ضمن بيام در كفتار هيجانى بررسى مى كنيم. بنابراين در اين بخش بـ به اله

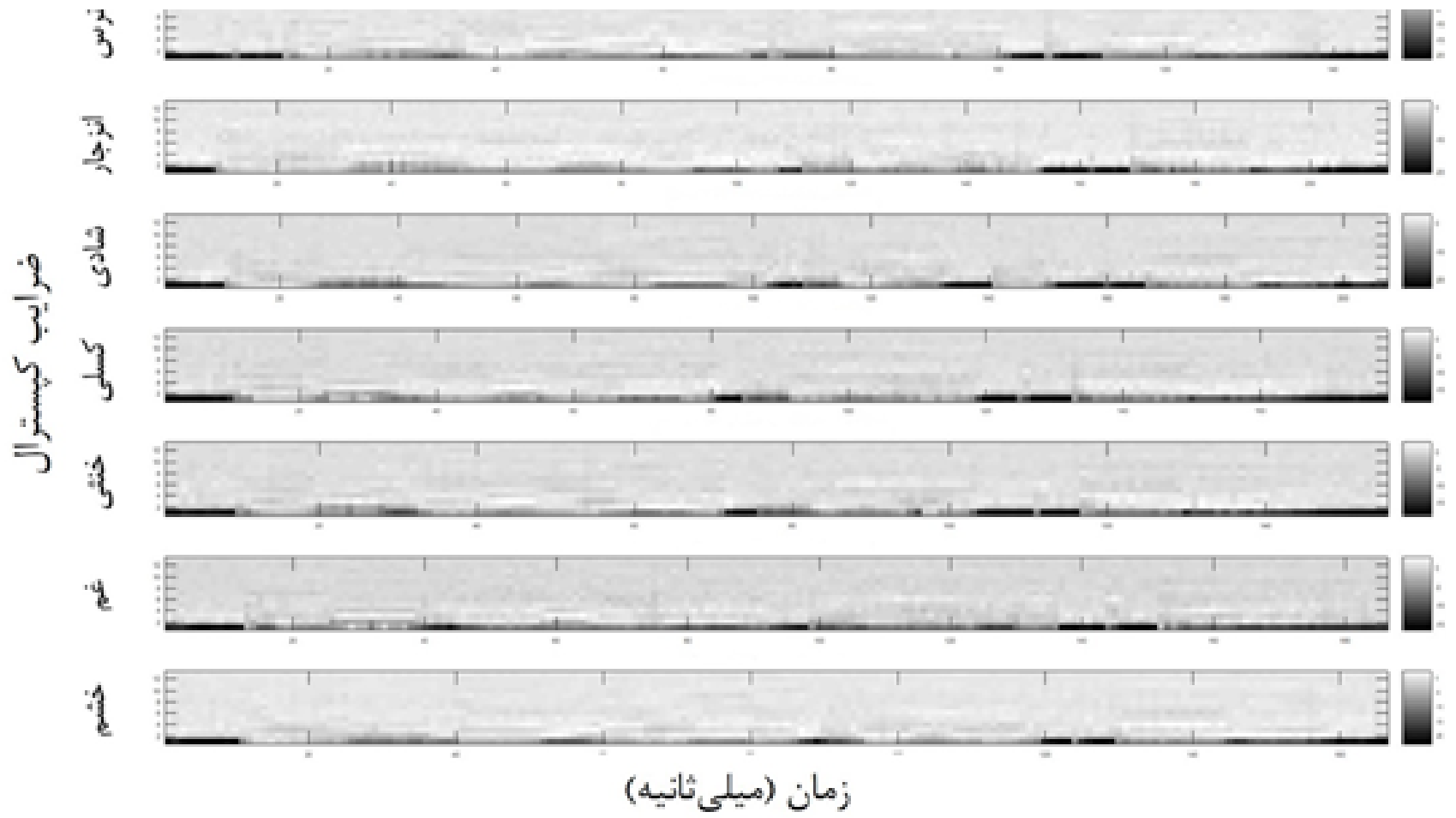

شكل r. ضرايب MFCC محاسبه شده براى يك پاره كَفتار كه توسط يك كوينده با هفت حالت هيجانى بيان شده است 
تحليل سيكنال روى ينجرههاى زمانى خاصى را فراهم مى آورند ( آ، Tr). معادله (Y))، معادله STFT را ارائه مى كند.

$\operatorname{STFT}(\tau, f)=\int x(t) g(t-\tau) e^{-i w t} d t, w=r \pi f \quad(\uparrow$

انتخاب اندازه ينجره مناسب براى محاسبهى STFT يك سيگنال از اهميت ويزهاى برخوردار است. با توجه به اصل عدم قطعيت، انتخاب ينجرههاى باريك باعث داشتن رزلوشن زمانى خوب و رزلوشن فر كانسى يايين مىشود، در حالى كه انتخاب ينجرههاى يهن باعث داشتن رزلوشن زمانى קايين و رزلوشن فر كانسى خوب مىشود. همجنين با توجه به نوع

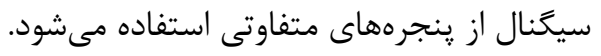

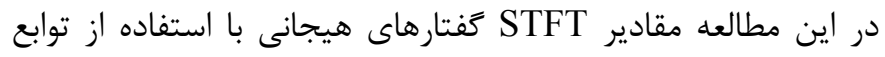

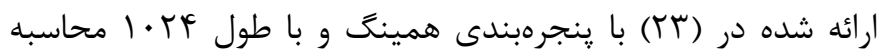

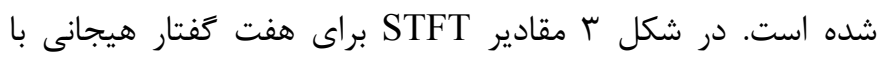
هفت حالت هيجانى متفاوت ارائه شده است. در اين كَتتارها كوينده و يارهفتتار بيان شده يكسان هستند و تنها نوع هيجان تغيير مى كند.
تبديل فوريه كوتاه مدت (STFT)

تجزيه طيفى ابزارى است كه امكان مطالعه و تحليل دقيقتر سيكنال

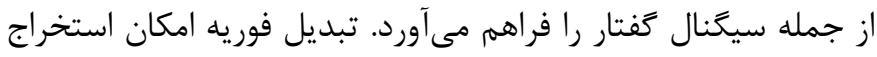

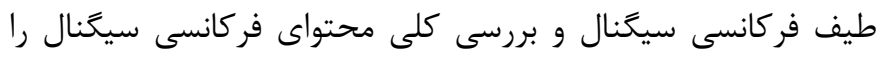

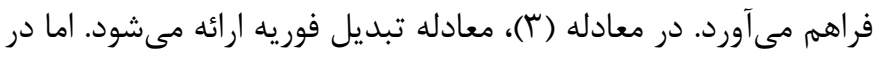

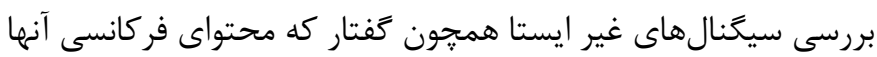
با زمان تغيير مى كند تنها بررسى فضاى فر كانسى كافى نيست و داشتن نمايش دو بعدى در فضاى زمان و فركانس ضرورى است. روش STFT امكان داشتن خنين نكاشتى را فراهم مى كند.

$$
F(w)=\int_{-\infty}^{\infty} x(t) e^{-i w t} d t, w=r \pi f
$$

با استفاده از STFT نكاشت زمان_فر كانس سيخنال بدست مى آيد. براى بدست آوردن STFT يك سيخنال ابتدا سيخنال به ينجرههاى

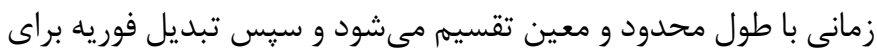
هر ينجره به طور مجزا محاسبه مىشود. به اين صورت STFT امكان

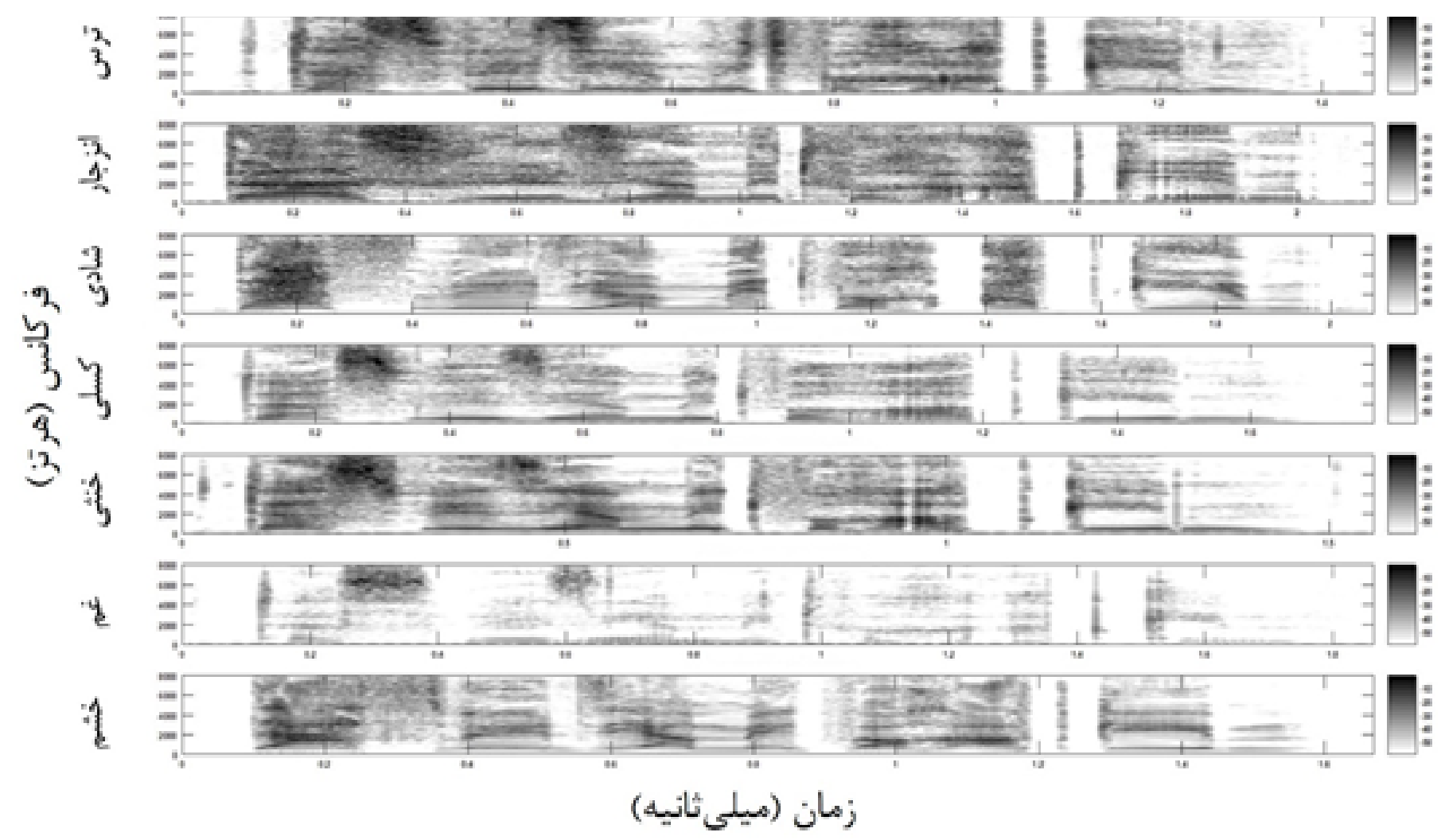

شكل r. مقادير STFT براى هفت كفتار هيجانى با هفت حالت هيجانى متفاوت كه گوينده و پاره گفتار بيان شده در آنها يكسان

زنده الهام گرفته شدهاند. شبكههاى عصبى مصنوعى از اتصال واحدهاى يردازشخرى به نام نورون در ييكربندىهاى گوناگون ساخته مىشوند كه
ساختار شبكه عصبى مصنوعى طبقهبندى كننده شبكههاى عصبى مصنوعى از ساختار و سيستم عصبى در موجودات 
آزمون مورد استفاده قرار گرفتند. همجنين در تمام بازشناسىها از تابع آموزش مبتنى بر الگوريتم يسانتشار گراديان مزدوج مدرج (Scaled) MATLAB در نرمافزار (conjugate gradient backpropagation كار گرفته شد. نتايج حاصل از بازشناسىها در جدول ا نشان داده شدهاند. با توجه به نتايج ارائه شده در جدول ا، تعداد لا نورون در لايه ينهان قرار داده شد. شكل ₹ نمايى كلى از شبكهى عصبى مورد استفاده ارائه مىدهد. تعداد نورونهاى لايه خروجى برابر هستند با تعداد حالتهاى يايه هيجانى مورد بازشناسى كه در اينجا اين تعداد V عدد مىباشد.
در حقيقت مدلى محاسباتى از سلول هاى عصبى يا نورونها در سيستمهاى عصبى موجودات زنده مىباشند. شبكه عصبى استفاده شده در اين مطالعه به عنوان طبقهبندى كننده، يك شبكه عصبى ييش خور (Feedforward) با يك لايه ينهان است. براى تعيين تعداد نورونهاى لايه ينهان هفت

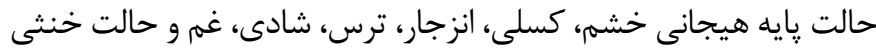
را با استفاده از ويزگى هاى STFT و تعداد مختلف نورون در لايه ينهان مورد بازشناسى قرار داديم. در تمامى بازشناسىهاى انجام شده • V درصد دادهها براى فاز آموزش، ها درصد براى فاز تأييد و ها درصى بر بر براى فاز

جدول ا. نتايج حاصل از بازشناسى هفت حالت پايه هيجانى توسط شبكه عصبى يِيخور با تعداد نورونهاى مختلف در لايه ينهان (درصد)

\begin{tabular}{|c|c|c|c|c|c|}
\hline در مجموع & آزمون & تأييد & آموزش & تعداد نورونها & مورد \\
\hline$\Lambda \varepsilon / 9$ & GN/A & V. & $q \mathbb{q} / f$ & 1. & 1 \\
\hline$M N / \Lambda$ & $V \Delta$ & $V I / r$ & $9 \Delta / \Delta$ & 10 & $r$ \\
\hline $91 / 1$ & $V T / \Delta$ & $\Lambda$. & $9 \Lambda / 4$ & $r$. & $r$ \\
\hline$M$ & $V \varepsilon / \mu$ & $V r / \Lambda$ & $9 \pi / 9$ & rD & $f$ \\
\hline $9 T / V$ & $V G / r$ & $V \Delta$ & $1 .$. & r. & $\Delta$ \\
\hline 91 & $V \Delta$ & $V \Psi / \Lambda$ & $91 / 1$ & ra & 9 \\
\hline$\Delta r / \varphi$ & $V I / r$ & $V / r$ & $\mathrm{MN} / \mathrm{A}$ & f. & $v$ \\
\hline
\end{tabular}
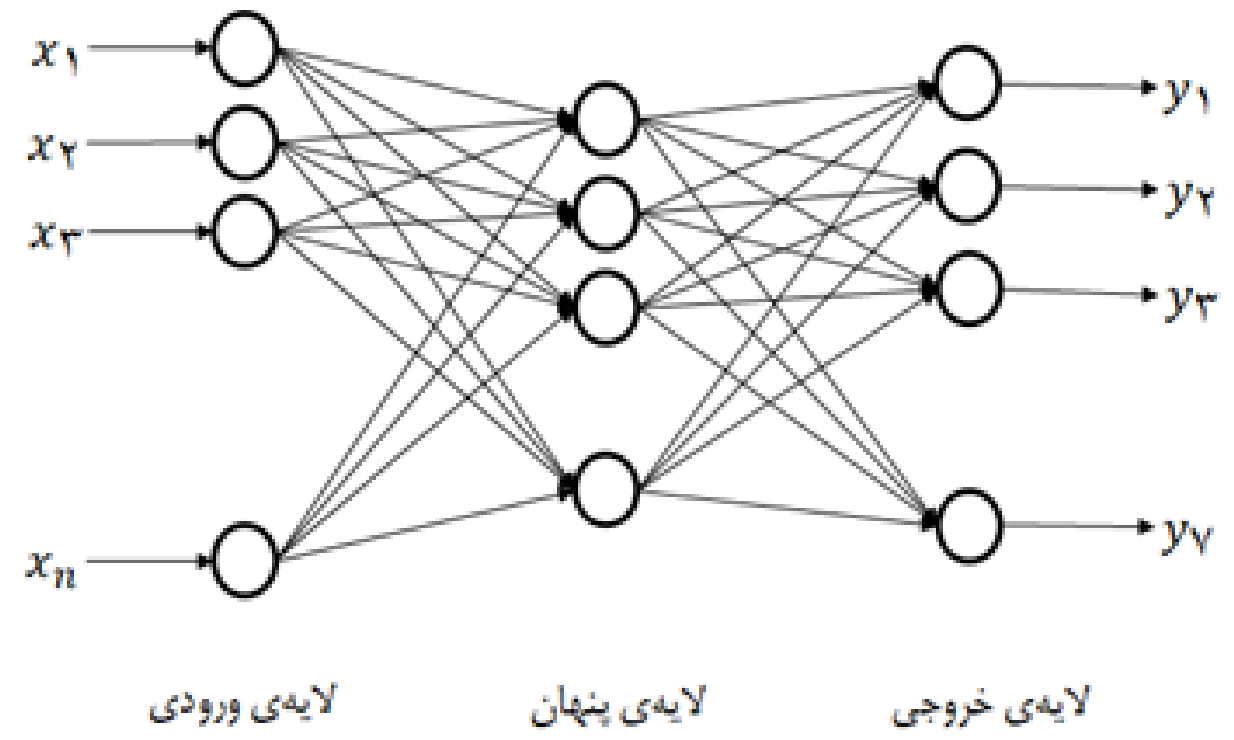

شكل f. نمايى كلى از קֶيكربندى شبكه عصبى طبقهبندى كننده

آموزش شبكههاى عصبى نورونها يا واحدهاى سازنده شبكههاى عصبى مصنوعى به صورت موازى عمل مى كنند. نورونها به صورت گستردهاى با يكديخر داراى 
مجموعه دادكانى هستيهم كه متشكل از كفتارهاى هيجانى باشد. همجنين هر نمونه با نام حالت هيجانى مشخص برجسب گَذارى شده باشد. به اين منظور در اينجا از يايعاهداده كفتار هيجانى Berlin استفاده شد (ض广). اين مجموعه دادكان شامل هسه نمونه گفتتار هيجانى است و داراى نمونههايى براى هفت حالت يايه هيجانى خشم، كسلى، انزجار، ترس، شادى، غم و حالت خنثى مىباشد. · ا گوينده شامل ه زن و ه مرد، · إياره كفتار مختلف را با توجه به اين هفت حالت يايه هيجانى ذكر شده بيان كردند و نمونهاى كفتار هيجانى اين يايگاهداده را توليد كردند. توليدكنندگًان يايگاهداده گفتار هيجانى Berlin از ميان تمامى نمونههاى توليد شده آنهايى را كه داراى نرخ بازشناسى بيش از • م درصد و طبيعى •و درصد بودند را انتخاب كردند و در قالب اين مجموعه دادكان ارائه دادند. هفت حالت پايه هيجانى خشم، كسلى، انزجار، ترس، شادى، غم و حالت خنثى نشاندهنده طبقههايى هستند كه مىخواهيم كفتارهاى هيجانى بازشناسى شده رابر اساس آنهاطبقهبندى كنيه. بردار خروجى شبكه عصبى مورد استفاده بر اساس اين هفت حالت يايه هيجانى مشخص مىشود. جدول r بردار خروجى براى هر حالت پايه هيجانى را نشان مىدهد.
اتصالاتى هستند. اين اتصالات عملكرد شبكه عصبى را مشخص مى كنند. همجنين با تنظيم مقادير (ارزشهاى) اين اتصالات مىتوان آنى شبكه عصبى را آموزش داد تا عملكرد ويزهاى را انجام دهد. آموزش به طور خلاصه عبارت است از فرآيندى كه وزنهاى بهينه شبكه عصبى تعيين مىشود (YY). از توابع آموزشى مبتنى بر الكوريتمهاى مختلفى همجون گراديان كاهشى (Gradient Descent) براى تنظيم وزنهاى شبكه عصبى استفاده مىشود. اين توابع آموزشى عبارتند از: يسانتشار ارتجاعى (Resilient Backpropagation)، گراديان مزدوج مدرج (Scaled Conjugate Gradient)، گراديان مزدوج

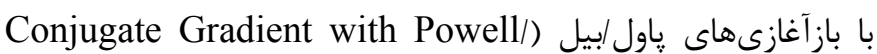
Fletcher-Powell (Beale Restarts Polak-(Conjugate Gradient One(Ribiére Conjugate Gradient (Step Secant و گراديان كاهشى (Gradient Descent). يايخَاهداده كَفتار هيجانى براى دستيابى به اهداف يزوهشى خود در اين مطالعه نيازمند استفاده از

\begin{tabular}{|c|c|c|}
\hline بر جسب & حالت هيجانى & مورد \\
\hline $1 \ldots \ldots$ & خشم & 1 \\
\hline$\cdot 1 \cdots \cdots$ & كسلى & $r$ \\
\hline. $.1 \ldots$ & انزجار & $r$ \\
\hline$\cdots \mid \ldots$ & ترس & f \\
\hline$\cdots \cdot 1 \cdot$. & شادى & $\Delta$ \\
\hline 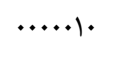 & غم & $q$ \\
\hline$\cdots \cdots \cdot 1$ & حالت خنثى & V \\
\hline
\end{tabular}

انتخاب ويزَى ها و تشكيل بردار ويزَى

هر نمونه كَفتار هيجانى را توليد شد. شكل ه حُكَنكى كاهش اندازه براى سا ضريب نخست MFCC را نشان مى دهدي. روند مشابهى براى ويزگى هاى STFT استخراج شده از نمونههاى كفتار

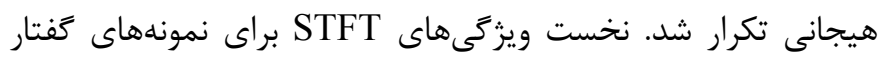

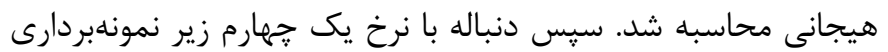

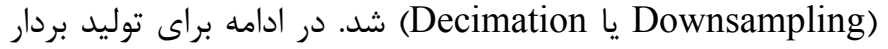

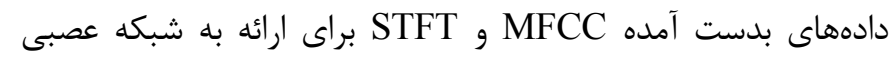

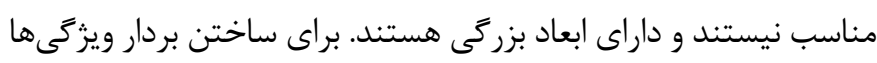

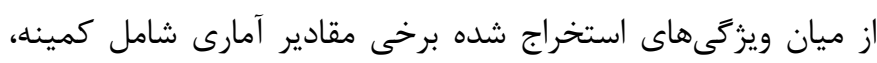

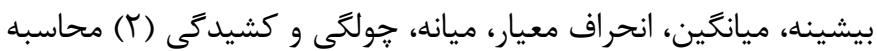
شدند. در اينجا سا ضريب نخست MFCC را داريم و هفت مقدار آمارى ذكر شده را براى هر ضريب محاسبه شد و به اين ترتيب بردار ويزگى براى 


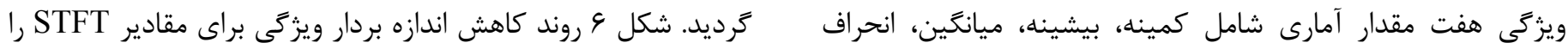

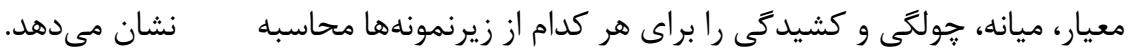

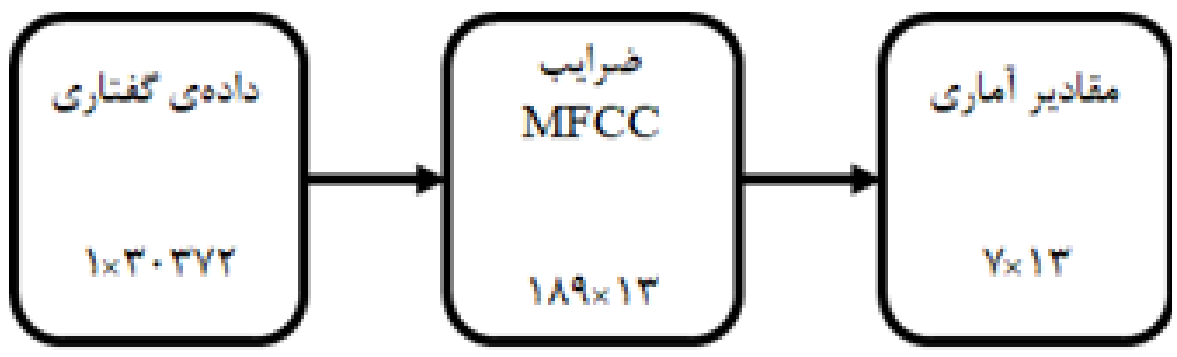

شكل ه. روند كاهش اندازه بردار ويزَى براى سا ضريب نخست MFC

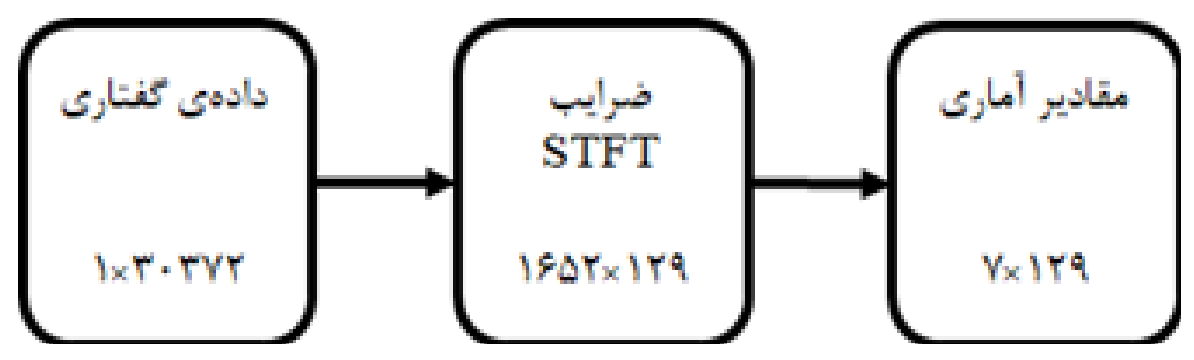

شكل צ. روند كاهش اندازه بردار ويزگى براى مقادير STFT

يافته ها

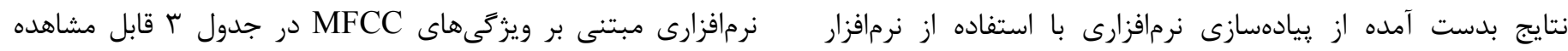

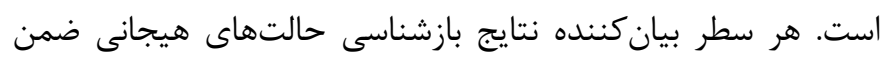
MATLAB R2016a

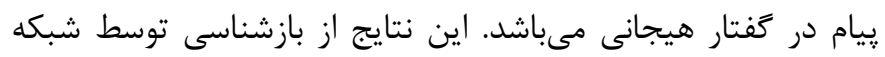

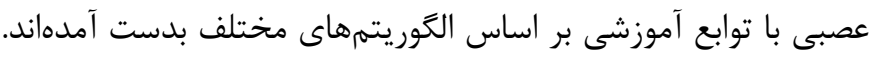
ويزَّى براى هر يك از نمونههاى كفتار هيجانى در يايخاهداده كفتار

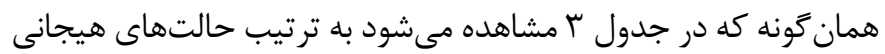
هيجانى Berlin محاسبه مى مود. در مرحله نحست، بر اساس خشم و غم نسبت به ساير حالتهاى هيجانى از نرخ بازشناسى بهترى برخوردار هستند و حالتهاى هيجانى انزجار و شادى با نرخ پإيينترى

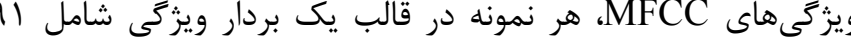

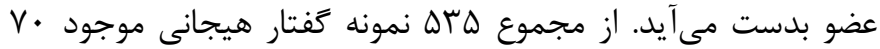
درصد براى آموزش، ها درصد براى تأييد و ها درصد براى آزمون بازشناسى مىشوند. شبكه عصبى مصنوعى ييشخور استفاده شد. نتايج حاصل از ييادهسازى

جدول r. نتايج بدست آمده از بازشناسى حالتهاى هيجانى بر اساس ويزگى هاى MFCC (درصد)

\begin{tabular}{|c|c|c|c|c|c|c|c|c|}
\hline در مجموع & حالت خنثى & 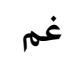 & 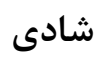 & ترس & انزجار & 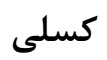 & خشم & الخوريتم تابع آموزش \\
\hline $4 \cdot / r$ & $\forall \& \mid \Lambda$ & $V \Delta / \Lambda$ & 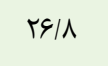 & $G T / r$ & $r \cdot / \boldsymbol{f}$ & $49 / 1$ & $\Lambda / \Delta$ & يسانتشار ارتجاعى \\
\hline$\Delta \xi / \Lambda$ & $\hat{Y N / 1}$ & $s V / V$ & r & $p q / r$ & $r \& / 1$ & $\Delta 9 / \Gamma$ & $1 \mathrm{M} / 1$ & گراديان مزدوج مدرج \\
\hline$\Delta 9 / 9$ & $\Delta V$ & $V V / T^{c}$ & 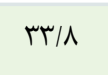 & $F V / \Lambda$ & $r F / \Lambda$ & $p q / 4$ & 19 & كراديان مزدوج با بازآغازىهاى پاول/بيل \\
\hline$\Delta T / q$ & $\Delta V$ & $9 \mathrm{~V} / \mathrm{V}$ & $\mid r / F$ & $\mid \varepsilon / F$ & $T / T$ & $\Delta \varepsilon / \Lambda$ & $1 \Delta$ & كراديان مزدوج فلجر_, «اول \\
\hline
\end{tabular}




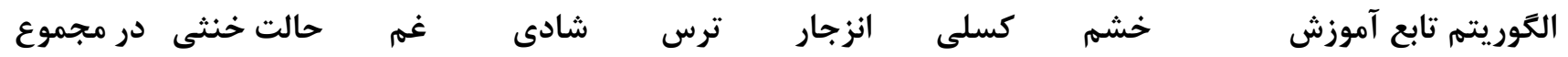

\begin{tabular}{|c|c|c|c|c|c|c|c|c|}
\hline GT/G & fr & $V V / T^{4}$ & ג/זr & $\Delta q / f$ & $\Delta \varepsilon / \Delta$ & $99 / V$ & $\Lambda \Delta$ & گَراديان مزدوج پِلاك_ ريبير \\
\hline$\Delta \Delta / \Delta$ & $\Delta \Delta / V$ & $q 4 / D$ & $r M / l$ & $\Delta r / \varphi$ & TN/K & $9 \cdot 10$ & $v \wedge$ & تك مرحلهاى متقاطع \\
\hline$r q / r$ & TE/ & GK/9 & $19 / V$ & $T I / V$ & 1.19 & 19 & זN/ & عَراديان كاهشى \\
\hline
\end{tabular}

حالتهاى مختلف هيجانى توسط شبكه عصبى مصنوعى ييشخور با استفاده از توابع آموزشى بر اساس الخوريتمهاى مختلف را ارائه شده است. با توجه به نتايج ارائه شده در جدول ل أ حالتهاى هيجانى خشه، غم و كسلى بانرخ بهترى بازشناسى شدهاند. هر جند در یارهاى از موارد حالت هيجانى غم به خوبى بازشناسى نشده است.
در مرحله دوم، بردار ويزگگى هر نمونه گفتار هيجانى مبتنى بر ويزگىهاى STFT بدست آمد. هر بردار ويزگى در اين مرحله شامل بـ • 9 عضو بود.

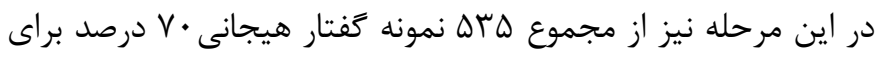
آموزش، ها درصد براى تأييد و ها درصد براى آزمون شبكه عصبى

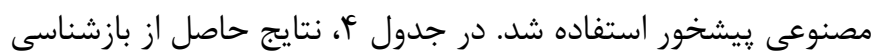

جدول f. نتايج بدست آمده از بازشناسى حالتهاى هيجانى بر اساس ويزَّى هاى STFT (درصد)

\begin{tabular}{|c|c|c|c|c|c|c|c|c|}
\hline در مجموع & حالت خنثى & 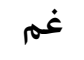 & 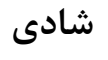 & ترس & انزجار & كسلى & خشم & الكوريتم تابع آموزش \\
\hline Trt & s/r & . & $F / T$ & $1 / f$ & . & $F \Delta / V$ & $91 / 4$ & ״س \\
\hline$\Delta 9 / \wedge$ & $\mu q / \mu$ & $91 / 9$ & $M T / 4$ & $r V / V$ & $r \cdot / \uparrow$ & $\Delta \Lambda$ & $9 r / 9$ & كراديان مزدوج مدرج \\
\hline$V T / V$ & $9 V / 1$ & $V V / A^{\mathcal{A}}$ & $r q / r$ & 9.19 & 9.19 & $V \varepsilon / \Delta$ & $9 \Delta / r$ & حراديان مزدوج با بازآغازىهاى ياول/بيل \\
\hline$\wedge \Delta / \wedge$ & $M / \Delta$ & $9 \pi / 0$ & $V F / \varphi$ & $V \Delta / T^{\top}$ & Av & $V \& / Q$ & $9 \vee / 9$ & كراديان مزدوج فلجر_ ياول \\
\hline$\Lambda \cdot / \mathcal{k}$ & $\Lambda T / r$ & ૧૬।^ & $r q / r$ & $\mathrm{~V} / \mathrm{V}$ & $G V / F$ & vq & $9 \% / 0$ & عراديان مزدوج يلاك_ رببير \\
\hline$\Lambda r / q$ & $V \Delta / q$ & $9 \Delta / r$ & $q V / Q$ & $\mathrm{~V} / \mathrm{V}$ & $\Lambda V$ & $\Lambda T / V$ & $94 / 0$ & تك مرحلهاى متقاطع \\
\hline$q V / V$ & $\Delta V$ & $৭ \& / \wedge$ & $\varphi q / r$ & $\Delta \& / \Delta$ & $r \Lambda / r$ & $99 / 1$ & $\wedge 9 / \wedge$ & كراديان كاهشى \\
\hline
\end{tabular}

وجه حالات هيجانى را بازنمايى كنند. در حالى كه در رويكرد دوم موضوع مورد بررسى انواع طبقهبندى كنندهها، طراحى و بهينهسازى آنها مىباشد. در اكثر يزوهشهاى انجام شده MFCC و مشتقات آن مؤن بيش از ساير ويزگى ها براى بازنمايى حالات هيجانى مورد استفاده قرار مى گيرند (ا، ؟). اين موضوع نشاندهنده توانمندى اين ويزگى ها براى بازنمايى حالات هيجانى مىباشد. همخام با اين :زوهش ها، شاهد

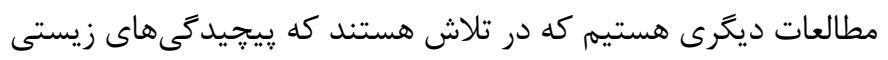
سيستم شنوايى را مورد بررسى قرار دهند و اين سيستم را مدلسازى كنند. در يزوهش انجام شده Golipour و Gazor سيستم شنوايى با

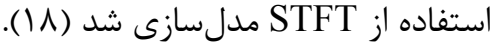
در اين بررسى، بازشناسى حالتهاى هيجان ضمن ييام در گفتار هيجانى
كفتار مؤثرترين ابزارى است كه انسانها از آن براى انتقال اطلاعات استفاده مى كنند. هر كفتار علاوه بر وازًّان و دستور زبان حاوى اطلاعات فراوان ديكرى همجون سن، جنسيت و حالت هيجانى گوينده آن نيز مىباشد. هيجان ضمن ييام كه گوينده در خلال كفتار خود آن را انتقال مى دهد از طبيعتى يويا برخوردار است. يزوهشهاى مختلفى ييرامون بازشناسى هيجان و حالتهاى هيجانى در كفتار هيجانى با رويكردهاى

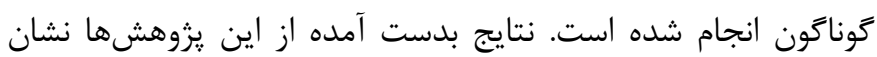
مى دهد كه مطالعه كمّى هيجان ضمن پيام در كفتار هيجانى بسيار دشوار است. يزوهشهاى انجام شده پيرامون بازشناسى هيجان كفتار با دو رويكرد قالب انجام مى گيرند (1). رويكرد نخست به بررسى ويزگ 
MFCC هيجانى، ويزَىهاى STFT بهتر از ويزَىهاى MFCC الكوىهاى هيجانى را بازنمايى مى كنند و براى بازشناسى تعداد بيشترى از هيجانات

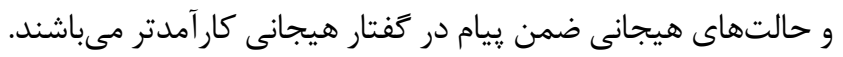

\section{نتيجه كيرى}

كفتار مؤثرترين شيوه ارتباطى است. هر كفتار شامل اطلاعات فراوانى

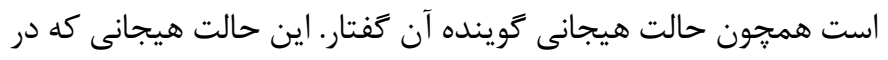
خلال كَفتار بيان مىشود و از طبيعتى يويا برخوردار است. در اين مقاله قابليت بازنمايى حالات هيجانى با استفاده از MFCC و STFT مورد ارزيابى قرار گرفتند. در يزوهشهاى بسيارى از MFCC براى بازنمايى حالات هيجانى استفاده شده است. اما نوآورى اين مطالعه استفاده از از براى بازنمايى حالات هيجانى در كفتار هيجانى است. نتايج

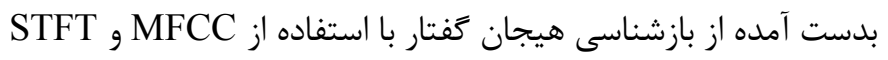

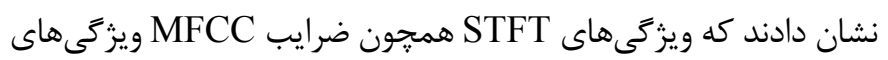
توانمندى براى بازنمايى حالات هيجانى هستند و در برخى موارد داراى عملكرد بهترى از MFCC إست.

\section{تشكر و قدرهانى}

اين مقاله حاصل از رساله دكترى علومشناختى-زبانشناسى در مؤسسه آموزش عالى علوم شناختى مىباشد.

\section{References}

1. Hasrul MN, Hariharan M, Yaacob S. Human affective (Emotion) behaviour analysis using speech signals: A review. In International Conference on Biomedical Engineering 2012 (ICoBE). 2012 Feb 27-28; Penang, Malaysia. pp. 217-22.

2. Demircan S, Kahramanlı H. Feature extraction from speech data for emotion recognition. Journal of Advances in Computer Networks. 2014;2(1):28-30.

3. Nwe TL, Foo SW, De Silva LC. Speech emotion recognition using hidden Markov models. Speech Communication. 2003;41(4):603-623.

4. Lalitha S, Geyasruti D, Narayanan R, Shravani M. Emotion detection using MFCC and cepstrum features. Procedia Computer Science. 2015;70:29-35.
مبتنى بر ويزگَىهاى MFCC و STFT مورد ارزيابى قرار داديه. براى انجام اين ارزيابى از نمونههاى كفتار هيجانى در يايخاه داده كفتار هيجانى Berlin حالت پايه هيجانى خشم، كسلى، انزجار، ترس، شادى، غم و حالت خنثى

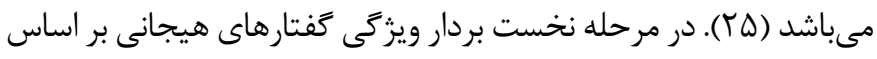

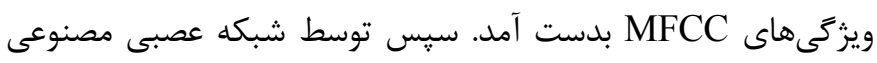

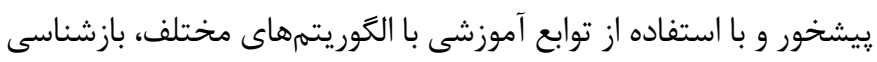
حالتهاى هيجانى مختلف در گفتار هيجانى انجام شد. مرحله دوم مشابه با مرحله نخست بود، با اين تفاوت كه بردار ويزگى كفتارهاى هيجانى بر اساس ويزگیىهاى STFT مىباشد. نتايج بدست آمده در مرحله نخست نشان داد كه به ترتيب حالتهاى هيجانى خشم و غم نسبت به ساير حالتهاى هيجانى با استفاده از ويزگىهاى MFCC با درصد بهترى بازشناسى مىشوند و حالتهاى هيجانى انزجار و شادى با درصد يايينترى بازشناسى شدند. از نتايج بدست آمده در مرحله دوم مشاهده

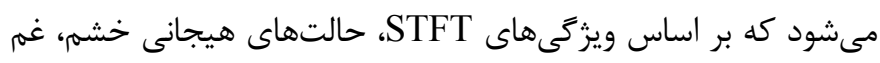
و كسلى با نرخ بهترى بازشناسى مىشوند. البته در يارهاى از موارد حالت هيجانى غم به خوبى بازشناسى نمىشود. در مجموع از مقايسه نتايج

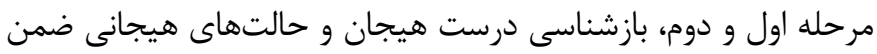
يیام در گفتار هيجانى با استفاده از ويزگى هاى STFT از نرخ بهترى برخوردار است. هر جند بردار ويزگى بدست آمده از ويزگى هاى STFT به مراتب داراى اعضاى بيشترى از بردار ويزگى بدست آمده از ويزگى هاى

5. Nicholson J, Takahashi K, Nakatsu R. Emotion recognition in speech using neural networks. Neural Computing \& Applications. 2000;9(4):290-296.

6. Franti E, Ispas I, Dragomir V, Dascalu M, Zoltan E, Stoica IC. Voice based emotion recognition with convolutional neural networks for companion robots. Science and Technology. 2017;20(3):222-240.

7. Ververidis D, Kotropoulos C. Emotional speech classification using Gaussian mixture models. In 2005 IEEE International Symposium on Circuits and Systems. 2005 May 23-26; Kobe, Japan. pp. 2871-2874. IEEE.

8. Cichosz J, Slot K. Emotion recognition in speech signal using emotion-extracting binary decision trees. In Doctoral 
Consortium. Proceeding Affective Computer Intelligent Interaction. Lisbon:Springer;2007.

9. Hua A, Litman DJ, Forbes-Riley K, Rotaru M, Tetreault J, Purandare A. Using system and user performance features to improve emotion detection in spoken tutoring dialogs. InNinth International Conference on Spoken Language Processing. 2006 Sep 17-21; Pittsburgh, PA, USA. pp. 797-800.

10. Wu C, Chuang Z. Emotion recognition from speech using ig-based feature compensation. International Journal of Computational Linguistics \& Chinese Language Processing (Special Issue on Affective Speech Processing). 2007;12(1):65-78.

11. Hoch S, Althoff F, McGlaun G, Rigoll G. Bimodal fusion of emotional data in an automotive environment. In Proceedings IEEE International Conference on Acoustics, Speech, and Signal Processing, 2005. 2005 Mar. 23; Philadelphia, PA, USA. pp. 1085-1088.

12. Fersini E, Messina E, Archetti F. Emotional states in judicial courtrooms: An experimental investigation. Speech Communication. 2012;54(1):11-22.

13. Albornoz EM, Milone DH, Rufiner HL. Spoken emotion recognition using hierarchical classifiers. Computer Speech \& Language. 2011;25(3):556-570.

14. Lee CC, Mower E, Busso C, Lee S, Narayanan S. Emotion recognition using a hierarchical binary decision tree approach. Speech Communication. 2011;53(9-10):1162-1171.

15. Motamed S, Setayeshi S, Rabiee A. Speech emotion recognition based on a modified brain emotional learning model. Biologically Inspired Cognitive Architectures. 2017;19:32-38. 16. Motamed S, Setayeshi S, Rabiee A. Speech emotion recognition based on brain and mind emotional learning model. Journal of Integrative Neuroscience. 2018;17(3-4):577-591. 17. Motamed S, Setayeshi S, Farhoudi Z, Ahmadi A. speech emotion recognition based on learning automata in Fuzzy Petri-net. Journal of Mathematics and Computer Science. 2014;12(3):173-185.

18. Golipour L, Gazor S. A biophysical model of the human cochlea for speech stimulus using STFT. In Proceedings of the Fifth IEEE International Symposium on Signal Processing and Information Technology, 2005. 2005 Dec 21; Athens, Greece. pp. 46-50. 19. Ayat S. Fundamentals of speech signal processing, Tehran:Payame Noor University Press;2008. (Persian)

20. Sahidullah M, Kinnunen T, Hanilçi C. A comparison of features for synthetic speech detection. Conference of the International Speech Communication Association (INTERSPEECH) 2015. 2015 Sep 6-10; Dresden, Germany. pp. 2087-2091.

21. Mallat S. A wavelet tour of signal processing the sparse way. $3^{\text {rd }}$ ed. Burlington:Academic Press;2009.

22. Mertins A. Signal analysis: Wavelets, filter banks, time-frequency transforms and applications. West Sussex, England:John Wiley \& Sons; 1999.

23. Wojcicki K. Speech Spectrogram. MATLAB Central File Exchange; 2020 [updated 23 July 2020 cited 23 April 2019]. https://www.mathworks.com/matlabcentral/fileexchange/29596-speech-spectrogram.

24. Forouzanfar M, Dajani HR, Groza VZ, Bolic M, Rajan S. Comparison of Feed-Forward Neural Network training algorithms for oscillometric blood pressure estimation. In 4th International Workshop on Soft Computing Applications 2010 Jul. 15-17; Arad, Romania. pp. 119-123.

25. Burkhardt F, Paeschke A, Rolfes M, Sendlmeier WF, Weiss B. A database of German emotional speech. In 6th Interspeech 2005 and 9th European Conference on Speech Communication and Technology 2005. 2005 Sep. 4-8; Lisbon, Portugal. pp. 1517-1520. 